\title{
ПОГОДНЫЕ ЯВЛЕНИЯ В ПРИРОДЕ В РУССКОЙ ЯЗЫКОВОЙ КАРТИНЕ МИРА
}

\author{
Weather Phenomena in Nature \\ in the Russian Language Picture of the World
}

Keywords: weather phenomena, linguistic picture of the world, folklore, omens, proverbs, riddles

Contact: МГПУ; annaandreevna99@yandex.ru, kolgsonya@gmail.com, Petropavlova.darya@yandex.ru

Каждый народ характеризуется своей культурой. Народное творчество отражает результаты художественной деятельности народа, оно выстраивается сквозь года, из поколения в поколение. Устное народное творчество вбирает в себя всю мудрость народа, его отношение к жизни.

Фольклор подразделяется на разные жанры, такие как: загадки, пословицы и поговорки, приметы, сказки, легенды, былины и другие. Каждый жанр имел свои черты и особенности, но все они отражали опыт наблюдения народа за окружающей действительностью. Фольклор служил в том числе источником просвещения: через народное творчество передавались научные знания о природе.

Одним из самых распространенных жанров устного народного творчества являются приметы. Обратимся к «Толковому словарю русского языка» С.И. Ожегова, в котором отмечается: 1. Отличительное свойство, признак, по которому можно узнать, кого-что-нибудь. Приметы весны. Особые приметы (характерные индивидуальные признаки). 2. Явление, случай, которые в народе считаются предвестием чего-нибудь. Верить в приметьл. Дурная примета. Есть приметы: просыпанная соль - к ссоре. Сбылась старая примета. ${ }^{1}$

\footnotetext{
${ }^{1}$ Режим доступа: https://slovarozhegova.ru/word.php?wordid=23881 (2021-03-22).
} 
Народные приметы - жанр, который отличается своим содержанием и объемом, структурой. С древности приметы носили бытовой характер, они подразумевали совет или наставление, которое давалось человеку с целью предотвратить или обозначить какое-либо явление или событие. Приметы также отражают причинно-следственные связи в природе.

Приведем в пример примету, которую достаточно часто можно услышать в речи людей: Ласточки низко летают $-\kappa$ дождю. В данной примете описывается такое погодное явление как дождь. Если рассматривать данную примету с научной точки зрения, то можно объяснить истинную причину этого явления.

Примету изучали орнитологи и энтомологи. Научное обоснование заключается в уровне влажности накануне дождя. Уровень влажности воздуха это количество влаги, которая содержится в одном кубометре воздуха. Уровень влажности зависит от температуры воздуха и атмосферного давления. Распределение влажности также зависит от местоположения, рода поверхности и рельефа земли, характера растительного покрова. По мере возрастания широты и убывания температуры абсолютная влажность понижается. В преддверии дождя атмосферное давление падает, а влажность повышается, тем самым оказывается влияние на полет насекомых. Во время полета на них оседает небольшое количество капель воды, которые скапливаются на крыльях. Это делает их массу больше. При изменении массы тела меняется масса крыльев, что приводит к затруднению полета. Именно поэтому насекомые «спускаются» ниже к земле. Вслед за насекомыми меняют свою траекторию полета и сами птицы, так как ласточки питаются в основном летающими насекомыми.

Если рассматривать данную примету с языковой точки зрения, то можно сделать выводы, что люди во время наблюдения за погодными явлениями обратили внимание на определенную закономерность: как только траектория полета ласточек меняется с одного уровня на другой, спустя небольшое количество времени, начинаются осадки. Люди определяли погоду исходя из наблюдения за птицами, не задумываясь об истинной причине данного явления.

Также существует и мистическая сторона этой приметы: многие народы России считают, что ласточки - это птицы, которые могут общаться с душами умерших людей. Люди связывали явление с этим фактом и были уверены, что, спускаясь ближе к земле, ласточки передают весточку родственникам. В следствие чего люди плакали, что и считалось причиной изменения погодных явлений. 
Приведем в пример еще одну примету, которую можно отнести к теме дождя: Воробьи купаются в пьли - к дождю. Рассмотрим примету с научной точки зрения. Ключ к разгадке данного явления также кроется в изменении влажности и атмосферного давления. При понижении атмосферного давления повышается активность паразитов, которые живут в перьях у птиц. Высокая активность вызывает у воробьев зуд, и для того, чтобы от него избавиться, они купаются в песке, тем самым очищая перья. Народ, наблюдая за данным явлением, видел определенную логику: птицы купались в песке - следом шел дождь.

В фольклоре существует множество разнообразных примет, которые раскрывают сущность погодных явлений. Большинству примет можно дать научное объяснение: Красный закат - летом к ветреной погоде, зимой - кморозу; Лягушки громко квакают - кясной погоде, тихо - к дождю; Перед стихией становится тихо; Сильная роса на траве - дождя не будет; Солнце село в облаках - жди дождя; Кузнечики стрекочут к хорошей погоде; Черемуха изветет к холодам; Паук плетет паутину - к ясному дню; Чайки сидят на воде к ясной погоде, и многие другие.

Таким образом, можно сделать вывод, что приметы имеют большое значение в устном народном творчестве. В них содержится мудрость и представления о мире, о явлениях природы. Анализ примет с разных точек зрения и поиск научного объяснения помогают узнать причину событий, а также взглянуть на привычный мир людей их глазами.

Одним из жанров народного творчества является загадка. В «Толковом словаре русского языка» С.И. Ожегова загадка определяется как изображение или выражение, нуждающееся в разгадке или истолковании. ${ }^{2}$ Иными словами загадка подразумевает под собой вопрос или задание, которое необходимо разгадать. С древнерусского языка «гадать» - означает 'размышлять', 'думать'

Возникновение загадки приходится на древние времена и имеет тесную связь с обрядами и ритуалами, которые имели важное значение для людей, а также сопровождали все значимые события. Изначально люди использовали иносказательную (тайную) речь для обмана растений и животных. В те времена люди боялись природы и верили, что повсюду злые и добрые существа, которые их слышат. Таким образом, с помощью загадок люди пытались воздействовать на природу.

\footnotetext{
${ }^{2}$ Режим доступа: https://slovarozhegova.ru/word.php?wordid=8022 (2021-03-22).
} 
На ранних этапах развития человеческого общества через загадки передавался житейский опыт и сведения о природе от старших поколений к младшим. Разгадки народной загадки, являясь общим достоянием, передаются как знание из поколения в поколение, и тот, кто не знает загадки, не сможет ее отгадать (Сендерович 2008).

Через загадки люди пытались постичь тайны природы. Затем загадки становились частью общественной жизни людей, использовались как средство для испытания мудрости и смекалки. И только спустя долгое время загадки стали использоваться в целях воспитания и развлечения. В Древней Руси загадки также связывают с тайной речью охотников. Древнерусские загадки прослеживаются в сказках, былинах, баснях и славянских мифах.

Рассмотрим более подробно русские народные загадки. Так как загадки, в частности, представляли собой сведения о природе, то многие из них можно объяснить с помощью научных знаний. Так, наблюдая за погодой, люди отмечали особенности и характерные признаки того или иного природного явления. Люди описывали их через загадку и пытались дать им объяснение. Например, рассмотрим следующую загадку: Вечером наземь слетает, ночь на земле пребывает, утром опять улетает. В данной загадке описано такое погодное явление как роса. С помощью наблюдений люди заметили, что существует такое явление природы, при котором мелкие капли влаги оседают на землю в результате утренней либо вечерней прохлады. С научной точки зрения образование росы связано с тем, что насыщенный влагой воздух преобразуется в жидкое состояние при понижении температуры. Появление капелек воды на земле связано с тем, что теплый воздух оседает на более холодную поверхность. А утром при повышении температуры воздуха влага выпаривается, и роса пропадает.

К загадкам, которые объяснимы с научной точки зрения, можно отнести следующие: Летом греет, зимой холодит (солнце); И в огне не горит, и в воде не тонет (лед, сосульки); Сперва блеск, за блеском треск, за треском плеск (молния); Зимой греет, весной тлеет. Летом умирает, осенью оживает (снег); Не огонь, а жжется (мороз) (Макшанов 2018).

Однако не все загадки имеют научное описание природных явлений. Погодные явления в таких загадках люди сравнивали с привычными им предметами быта, домашними животными и птицами, частями тела. Для описания природного явления люди проводили аналогию между тем или иным образом, который возникал в сознании. Например, часто погодные условия описываются с характеристиками, присущими определенным животным: Конь бежит, земля 
дрожит (гром). Ударную волну и звук, вызванные громом, народ сопоставлял со звуками, возникающими при передвижении коней. Конь в древние времена считался атрибутом высших языческих богов, был связан с культом плодородия, а также считался проводником на «тот свет». Люди боялись грома и считали, что это посланец неба, именно поэтому не делали никаких работ во время данного погодного явления, чтобы не привлечь нечистую силу. В погодном календаре гром показывал будущую погоду и определял урожай.

К загадкам, в которых погодные явления сравниваются с характеристиками животных и птиц, можно отнести следующие: Летит птица орел, несет в зубах огонь, посередине его человечья смерть (молния); В избе баран ревет (холод); Беленька собачка в подворотню глядит (сугроб); Сивые кабаны все поле облегли (туман); Гуляет в поле, да не конь. Летает на воле, да не птица. (метель). Загадки, в которых погодные явления сравниваются с частями тела: Без рук, без ног, а стучит (ветер); Стучит без рук, бег огня горит (гроза); Без рук, без ног, а рисовать умеет (мороз). Загадки, в которых погодные явления сравниваются с предметами быта: Крашенное коромысло через реку повисло (радуга); Скатерть бела весь свет одела (снег); Старо лукошко, новый покрой (пруд).

Таким образом, мы можем сделать вывод, что загадки несли в себе большой смысл для народа, именно с их помощью люди передавали знания об окружающей действительности. Так, многие народные загадки о погодных явлениях в современном мире можно объяснить с научной точки зрения. Однако если рассматривать народные загадки с точки зрения языковой картины мира, то можно проследить тенденцию описания погодных явлений с помощью предметов и животных, которые присутствовали в повседневной жизни людей.

Далее рассмотрим погодные явления в русской языковой картине мира, отраженные в пословицах. В «Толковом словаре русского языка» Д.Н. Ушакова пословица - это «краткое образное законченное изречение, обычно ритмичное по форме, с назидательным смыслом» ${ }^{3}$. В народном творчестве существует большое количество пословиц и о воле, и о счастье, и о добре и зле, о любви, о здоровье, о правде и лжи, об уме, о трудолюбии, богатстве и бедности и т.д. Так или иначе, через это жанр устного народного творчества передавалась человеческая мудрость из поколения в поколение.

Языковая особенность пословиц состоит в том, что в кратком изречении отражается прожитый опыт людей, содержится поучительный смысл через образ, в частности, через образ погодных явлений. Если проанализировать пословицы,

\footnotetext{
${ }^{3}$ Режим доступа: https://biblioclub.ru/?page=dict\&dict_id=117 (2021-03-22).
} 
связанные с погодой, можно увидеть связь: между ней и человеческой жизнью, испытаниями и радостью.

Почему же люди отражали свои жизненные невзгоды или счастье в пословицах через погодные явления? Дело в том, что большая часть жизни русского народа была связана с сельскохозяйственной деятельностью, а она неотъемлемо зависела от погоды. Например, если в сезоне были сильные дожди или засуха, то урожай погибал, соответственно, наступал голод. Поэтому русский народ часто сравнивал негативные жизненные испытания с дождем, тучами, ветром и морозом, ср. Поднимутся тучи - дождь будет, пойдут речи - ссора будет. Рассмотрим данную пословицу с научной точки зрения. Туча - это темное, густое облако. Как она образуется? Высоко в небе намного холоднее, нежели на поверхности земли. Пар, поднимающийся высоко в воздух, превращается в капельки. Эти капельки образуют облако. Нижний край тучи становится тяжелее, поскольку сама туча состоит из «толстых» капелек воды, в следствие чего капли не могут держаться в воздухе и начинают падать на землю. Это явление называется дождем (Тарасов 2016). В пословице слово «речи»как споры, выяснение отношений отображает образ тучи, которая поднимается, а «ссора»дождь, т.е. следствие тучи. Иными словами, когда люди начинают спорить, доказывать что-то сильнее и сильнее, начинается ссора. Примеры подобных пословиц: Сбежались тучи в одну кучу - быть ненастью; Из тучи все в грозу выйдет; Ветер и море кольишет. Вместе с тем стоит отметить другую пословицу: Не все тучи с собой дождь несут. Она несет в себе мудрую мысль, что даже в сложных жизненных ситуациях не всегда будет печальный исход.

Пословицы с подобным смыслом: Из большой тучи да малая капля; Om большой тучи не всегда много дождя. С научной точки зрения, объяснение содержится в следующем: все зависит от облаков. Существует четыре вида облаков, по виду которых можно понять, будет ли дождь, гроза или нет. Первый вид облаков - кучевые. В солнечный день лучи греют землю, которая греет воздух, расположенный прямо над ней. Нагретый воздух поднимается наверх и образует небольшие пушистые облака. Они похожи на вату и являются признаком «хорошей погоды». Второй вид облаков - кучево-дождевые. Если кучевые облака увеличиваются и растут по высоте, то это признак того, что будет сильный дождь. От кучевых они отличаются тем, что недалеко от земли кучеводождевые облака четко оформлены, однако с высотой начинают становиться более дымчатыми по краям. Такой переход свидетельствует на то, что облако состоит уже не из капель воды, а из кристаллов льда. Чаще всего их можно увидеть летом: когда утренние кучевые облака днем превращаются в кучево- 
дождевые. Третий вид - перистые облака. Они формируются в высоких слоях атмосферы, являются дымчатыми, поскольку состоят полностью из кристаллов льда, падающих в атмосфере. Если перистые облака начинают покрывать большую площадь неба, становятся ниже и толще, то, скорее всего, в ближайшие 12 часов пойдет дождь. Четвертый вид - слоистые облака. Это низко расположенная, непрерывная облачная простыня, покрывающая небо. Формируются такие облака медленно восходящим воздухом и несильным ветром, который покрывает влажным воздухом холодную землю или поверхность моря. Эти облака достаточно тонкие, что дождь из них вряд ли пойдет. ${ }^{4}$ Таким образом, приближение дождя зависит от вида облаков, а каждую пословицу можно рассмотреть с разных точек зрения.

Как уже отмечалось ранее, русский народ часто использовал в пословицах образ погодных явлений. Пословицы о дожде, о тучах, о ветре по большей части отражают жизненные невзгоды людей, однако существуют и те, которые описывают урожайный или неурожайный сезон, сравнивая его с таким природным явлением, как снег. Возьмем к примеру пословицу: Больше снега на полях, больше хлеба в закромах. Аналогами ее являются также: Задержишь снег на полях зимой-будешь с хлебом осенью; Снег глубок-год хорош; Зима без снега - лето без хлеба.

Русский народ ожидал появление снега, поскольку считал, что он помогает зимовать посевам зерновых. Стоит отметить, что зерновые культуры, в свою очередь, являются важной группой в хозяйственной деятельности человека, так как дают зерно, сырье для многих отраслей промышленности и корм для животных. С научной точки зрения, если в пословице речь идет об озимой пшенице, тогда снежный покров действительно защищает ее от сильных морозов и ветра. Она вымерзает при низкой температуре, а значит, при отсутствии снега хорошего урожая может не быть. В обратном случае - при формировании глубокого снежного покрова, пшеница способна выдержать (Клещенко 2013). Наряду с этим, важно отметить, что снег хоть и важен для того, чтобы пшеница благополучно перезимовала, однако существуют и другие факторы, влияющие на урожай, а именно: качественны ли семена, плодородна ли почва, какие были сроки посева, как ухаживали за посевами и т.д. Отсюда следует, что в пословицах, отражающих урожайный или неурожайный сезон, нельзя сказать однозначно, необходимо учитывать многие факторы.

\footnotetext{
${ }^{4}$ Режим доступа: https://habr.com/ru/post/374459/ (2021-03-14).
} 
В заключение следует отметить особое значение устного народного творчества в описании погодных явлений. Как мы уже сказали ранее, каждый народ является олицетворением своей собственной культуры, а отражением народа является его устное народное творчество. Во многом благодаря ему люди накапливали мудрость и жизненный опыт, познавали окружающую действительность, сохраняя и передавая их из поколения в поколение. Люди формировали представления о природе и природных явлениях, фольклор являлся одним из главных источников получения информации.

\section{Summary}

The article is devoted to the study of weather phenomena in the Russian linguistic picture of the world reflected in folklore. For example, in signs, riddles and proverbs. The analysis of the signs showed that the signs help to find out the cause of events as well as look at the familiar world of people through their eyes. If we consider folk riddles from the point of view of the linguistic picture of the world, we can trace the tendency to describe weather phenomena with the help of objects and animals that were present in the daily life of people. The linguistic peculiarity of proverbs is that through the image of weather phenomena we can see the connection between them and human life, trials and joy.

\section{Литература}

Астахова, А.М., Базанова, А.М., Путилова, Б.Н. Загадки. Ленинград: Наука, 1968.

Ирлык, А. Народные приметы, пословицы и поговорки о погоде. Nauka.Club. 2021. Режим доступа: https://nauka.club/literatura/stikhi/narodnye-primety-opogode.html (2021-03-23).

Клещенко, А. «Много снега - много хлеба»: правдива ли пословица? Аргументы и факты. 26.03.2013.

Макшанов, С. Русские народнье загадки. Москва: АСТ, 2018.

Ожегов, С.И. Толковый словарь русского языка. Режим доступа: https://slovarozhegova.ru/ (2021-03-22).

Орлова, О.С. Происхождение загадки. Вестник ММА. 2017 (1), с. 192-197. 
Селянгина, К.Н. (сост.) Календарь народных примет погоды на все дни года. Режим доступа: https://royallib.com/book/selyangina_klara/kalendar_narodnih _primet_pogodi_na_vse_dni_goda.html (2021-03-23).

Сендерович, С.Я. Морфология загадки. Москва: Языки славянской культуры, 2008.

Тарасов, Л. Почему образуются облака? Наука и жизнь. 2016 (7). Режим доступа: https://elementy.ru/nauchno-populyarnaya_biblioteka/433212/Pochemu _obrazuyutsya_oblaka (2021-03-24).

Ушаков, Д.Н. Толковый словарь русского языка. Режим доступа: https://biblioclub.ru/?page=dict\&dict_id=117 (2021-03-22).

От примет к научному подходу. Режим доступа: https://www.culture.ru/materials/ 163222/ot-primet-k-nauchnomu-podkhodu (2021-03-23).

Шесть типов облаков, которые нужно знать - и что они рассказывают о погоде. Режим доступа: https://habr.com/ru/post/374459/ (2021-03-14). 